\title{
A LÍNGUA BRASILEIRA NO DISCURSO DO SAMBA: DE NOEL ROSA A CAETANO VELOSO
}

\author{
FRANCISCO ANTONIO ROMANELLI ${ }^{1}$
}

Faculdade de Filosofia, Ciências e Letras Eugênio Pacelli

Universidade do Vale do Sapucaí

Av. Pref. Tuany Toledo, 470 - 37550-000 - Pouso Alegre - MG - Brasil

faromanelli@gmail.com

Resumo. O presente texto tem por escopo analisar o discurso sobre a língua brasileira, de uso nacional, quando confrontada com a língua colonizadora, institucionalizada, o português de Portugal, na canção popular, por meio de textos recortados de canções que balizaram a discussão, em 1933 e em 1984. Na canção popular, a discussão que evidencia os discursos sobre a língua brasileira foi inaugurada por Noel Rosa, em "Não tem tradução", e posteriormente retomada por Caetano Veloso em "Língua”. Pela análise do discurso, buscamos compreender como a linguagem, nele, se manifesta e produz sentidos, concluindo que o músico popular, no mundo da canção, se ocupou da discussão sobre a língua brasileira.

Palavras-chave: língua brasileira; multiplicidade linguística; Noel Rosa; Caetano Veloso.

\begin{abstract}
The present text has the purpose of analyzing the discourse about the Brazilian language, of national use, when confronted with the colonizing, institutionalized language, the Portuguese of Portugal, in the popular song, through texts cut of songs that marked the discussion in 1933 And in 1984. In the popular song, the discussion that evidences the discourses on the Brazilian language was inaugurated by Noel Rosa, in "Não tem tradução", and later retaken by Caetano Veloso in "Lingua". By the analysis of the discourse, we sought to understand how language manifests itself and produces meanings, concluding that the popular musician, in the world of song, dealt with the discussion about the Brazilian language.
\end{abstract}

Keywords: Brazilian language; linguistic multiplicity; Noel Rosa; Caetano Veloso.

1 Doutorando no Programa de Pós-Graduação em Ciências da Linguagem (UNIVÁS). http://lattes.cnpq.br/8800977782955690. 
As palavras dos letrados brasileiros confundem-se com os perfumes das flores das selvas nacionais, o canto dos sabiás, e os gritos das arapongas, o rebombo das cachoeiras e a altitude das serras...

A língua brasileira espelha nas palavras, a alma dos brasileiros e a feição das cousas brasileiras.

Bricio Cardoso ${ }^{2}$

\section{Introdução}

Não é de pouco que se discute as variações sofridas pelo português falado no Brasil e que o distanciam daquele português falado em Portugal. No Brasil, a Língua já era múltipla desde muito antes da colonização portuguesa. Afinal, quando os colonizadores aqui fincaram bandeiras e pés, as nações indígenas já se comunicavam por nada menos que cerca de 1.300 línguas nativas, das quais ainda hoje restam 264 ativas $^{3}$.

Além disso, os primeiros colonizadores e outros aventureiros portugueses que por aqui aportaram, logo após a chegada no território brasílico, sentiram necessidade de se comunicarem com os nativos, seja para "domesticá-los" e atraí-los, como escravos ou colaboradores, para o pesado trabalho de "inauguração civilizatória" da terra, seja para catequizá-los (afinal, a missão mais nobre da conquista portuguesa de territórios ignaros era a salvação das almas eternas dos povos autóctones), seja para estabelecer o império da lei sob governo da bandeira do reino português (MARIANI, 2008, p. 35). Os próprios colonizadores vinham de regiões diversas de Portugal e, por isso, "Não foi, como pensam muitos [...] o português disciplinado grammaticalmente, o português dos classicos, o que veiu para o Brasil na bocca dos colonos, mas o velho e genuíno português do povo, rude e inculto" (SANCHES, 1940, p. 218).

Os colonos, em número infinitamente inferior aos nativos, e os religiosos, Jesuítas, que buscavam a catequização destes todos, tiveram que se adaptar a uma língua adequada à comunicação geral. "Deste contato entre língua indígena e diversas variedades linguísticas regionais e sociais portuguesas foi criada uma língua 'franca' para que os colonizadores pudessem estabelecer um contato efetivo com os índios que também não entendiam o português" (PIRES, 2009, p. 2). O "Tupi moderno", falado pelos nativos ao longo da costa do país, acaba sendo escolhido e conformado às necessidades do momento e, com as devidas influências e interferências dos colonizadores, acabou por constituir a língua brasílica, adotada como a língua geral da colônia (BIZIKOVÁ, 2008, p. 6).

A língua geral se estabiliza e domina as comunicações até maio de 1757. "Tamanha foi a influência da língua tupy, que, até o começo do século XVIII senhoreou ella inteiramente o idioma" (SANCHES, 1940, p. 218), após o que, pela "Lei do Diretório dos Índios", foi imposto, por ordem do Marquês de Pombal, o ensino e o uso exclusivo do português em terras brasileiras, além de se determinar a saída dos jesuítas da colônia (PIRES, 2009, p. 3). Eram eles, provavelmente, os maiores incentivadores e divulgadores

\footnotetext{
2 Tratado da Língua Vernácula, 1875. Citado por Edgard Sanches, in Língua Brasileira, 1940, tomo 1, p. 180.

${ }^{3}$ Dados obtidos no site http://basilio.fundaj.gov.br/; acesso em agosto de 2016.
} 
do uso da língua geral, a ponto de o padre José de Anchieta a "gramatizar" na obra Artes de gramática da língua mais usada na costa do Brasil (GUIMARÃES, 2004, p. 25).

Ademais, os escravos africanos trouxeram muitas línguas maternas, diferentes entre si. Pelo final do século XIX e começo do século XX, o incentivo ao trabalho do imigrante, para substituir a mão-de-obra negra, recém liberta, fez emigrar uma enorme quantidade de europeus para o Brasil, com línguas diversificadas, que, neste lado do Atlântico, uniu comunidades em torno de falares iguais. Com a ascensão de Getúlio Vargas ao poder, em 1930, o português foi normatizado como língua oficial do Brasil.

Procura-se, neste trabalho, refletir sobre os sentidos que, no contato com o mundo da canção popular, as alterações linguísticas, justificadores da luta pelo reconhecimento de uma língua brasileira produziram. A linguagem, nesse foco, é entendida como um fenômeno social, que se materializa por letras de canções do samba dito "malandro", (ou "samba duplex" ou "música de fresta"). O desate material do discurso malandro no samba é a língua textualmente consolidada na forma de letras de canções populares, não obstante a chamada "malandragem do samba" seja fruto da união harmônica da letra com a melodia, o ritmo e a interpretação. Convém, por isso, lembrar que o corpus deste trabalho é constituído por textos de letras de canções (deixando de lado a natural interferência de melodia e ritmo) e, nelas, analisaremos como a memória do discurso, o interdiscurso "faz funcionar a língua em um presente", ou seja, analisar como o exterior da enunciação "constitui sentidos no acontecimento" (GUIMARÃES, s/d., p. 3). Procura-se, pois, sob orientação da Análise do Discurso proposta por Michel Pêcheux e Eni P. Orlandi, discutir os sentidos produzidos pelas canções em análise e materializados nos textos das respectivas letras.

Por ser a língua passível de falhas, sempre possibilitando interpretações e o contato com sentidos diversos, a canção popular brasileira, no "samba malandro", se utilizou fartamente das possibilidades de ruptura próprias da incompletude da língua. Os sentidos sempre podem ser outros, e tal "fresta" foi um dos motores da malandragem perpetrada pelo samba, "porque são várias as linguagens possíveis, porque a linguagem se liga necessariamente ao silêncio, porque o sentido é uma questão aberta, porque o texto é multidirecional enquanto espaço simbólico" (ORLANDI, 2004, p. 18).

\section{A língua brasileira e a malandragem do samba polissêmico: de Noel Rosa a Caetano Veloso}

"A análise concreta de uma situação concreta pressupõe que a materialidade discursiva em uma formação ideológica seja concebida como uma articulação de processos", isto é, um entretecimento de diversas determinações ideológicas, saberes e discursividades prévias, de origem inatingível e delimitações inconcebíveis, pois "o discurso [...] não é um conjunto de enunciados portadores de uma, e até mesmo várias significações. É antes um processo que se desenvolve de múltiplas formas, em determinadas situações sociais" (ORLANDI [retomando Pêcheux], 1995, p. 112) e isso porque "A especificidade da análise de discurso está em que o objeto a propósito do qual ela produz seu resultado não é um objeto linguístico, mas um objeto sócio-histórico onde o linguístico intervém como pressuposto" (ORLANDI, 1995, p. 112). 
Neste trabalho, procura-se derivas de sentidos considerando-se a historicidade que constrói ou que é construída pelas condições de produção dos textos do corpus e pelas circunstâncias de sua enunciação, lembrando que entre a canção de Noel Rosa (1933) e a de Caetano Veloso (1984) medeia meio século de grande agitação e de transformações sócio-artístico-culturais. Questiona-se quais os sentidos produzidos pelo abrasileiramento da língua na canção popular, em tais pontos sócio-históricos, extraídos, no domínio enunciativo dos compositores, pelo uso de possibilidades parafrásticas e polissêmicas. Paráfrase e polissemia são utilizadas, neste texto, segundo o entendimento da Análise do Discurso, ou seja, a paráfrase como a "relação do dizer com outros dizeres" e a metáfora como "os deslizamentos, as derivas, que, dando visibilidade à historicidade, permitem compreender o trabalho da ideologia" (ORLANDI, 2012, p. 51).

Tais possibilidades, a par de indispensáveis na construção discursiva, pois "todo o funcionamento da linguagem se assenta na tensão entre processos parafrásticos e processos polissêmicos" (ORLANDI, 2015, p. 34), são utilizadas pelo sambista "malandro" com mestria para, propositalmente, confundir sistemas políticos autoritários, de certa restrição a dizer certas coisas que poderiam fazer certos sentidos a que os compositores estavam submetidos. Assim, diz-se, pela prática do silêncio, da paráfrase e, mais sistematicamente, da polissemia, o que não se pode dizer em um jogo astuto entre a paráfrase e o silêncio. Como nos ensina Eni Orlandi (2012, p. 131), "a polissemia é função da incompletude e o silêncio é sua matéria".

O samba "malandro" é consequência típica do uso acentuado de síncopas nos ritmos afrodescendentes, condição que permite a "falha" de acentuação no tempo tido como adequado à marcação rítmica forte e a troca do local de acentuação, fortalecendo o tempo "fraco" e silenciando ou enfraquecendo o tempo "forte", o que causa um "manquitolado" no balanço da canção. Essa dissincronia rítmica é filha da hábil prática dos silêncios/pausas, que acabam comandando a linha melódica e a letra da canção. E é por causa dessa prática de tempos e pausas que o samba se dá o poder de ser uma língua musical adequada aos efeitos polissêmicos: "o silêncio permite compreender a incompletude na base da interpretação, dos trajetos de sentidos, dos deslocamentos dos sujeitos, movimento contínuo entre a repetição e a diferença" (ORLANDI, 2012, p. 131).

As línguas, em qualquer sociedade, serão sempre muitas e que poderiam ser resumidas, com Orlandi (2009, p. 18), em duas possibilidades marcantes: língua imaginária e língua fluida. Enquanto a língua imaginária é aquela formalizada, a "língua sistema" que procura normatizar toda possibilidade de padronização - e, portanto, de funcionamento absoluto apenas no imaginário -, a língua fluida é aquela que efetivamente se fala; é a "língua movimento", insubmissa e insubordinada a arcabouços rígidos e fórmulas definitivas, impossível de ser contida, encontro da historicidade, da ideologia e do inconsciente (idem).

Em uma nação onde se estabelece uma língua oficial ${ }^{4}$, caso do Brasil, esta língua, em sua formulação normativa, é a língua imaginária: os mecanismos políticos se movimentam para definir, por regra, limites e potencialidades, demarcáveis semântica e gramaticalmente. No entanto, as línguas formais, praticadas, passam por um processo

\footnotetext{
4 “A língua oficial resulta [...] de uma decisão de Estado que exerce pressão normativa sobre os aparelhos de Estado, notadamente o judiciário e a Escola, impondo essa língua como aquela exigida aos cidadãos na sua relação com a estrutura administrativa estatal” (FONTANA, 2013, p. 275).
} 
constante de alteração e de dispersão, dependente da posição profissional ou sóciohistórica do falante, efeito que fará com que as línguas sejam sempre múltiplas. A multiplicidade linguística é consequência inevitável da possibilidade humana de simbolizar, idealizar e metaforizar, de provocar desvios, deslizes e deslocamentos no processo de buscar a inatingível paráfrase perfeita, a impossível interpretação exata. Como não poderia deixar de ser, e como acentua Eduardo Guimarães (2005[b], p. 22), o "Brasil é um país multilíngue". Apesar de tal multiplicidade de falares no cotidiano nacional, em todos os rincões, oficialmente invoca-se absoluto unilinguismo, e os falares múltiplos são tidos como "desvios" da língua padrão, que devem ser silenciados. É a ideologia dominante da construção da identidade nacional: uma mesma nação, um mesmo povo, uma mesma língua (Idem). E, o mais curioso é que a língua instituída, língua oficial, por ser ideal, mítica, utópica, vai ser, sempre, além de inatingível, a menos ou quase nunca plenamente usada.

A fixação de normas sempre será, segundo Marcos Bagno (2013, p. 18), um trilho estreito marcado pela gramática tradicional, que funciona como o "sapatinho de cristal de Cinderela", que "só cabe no pé de alguns poucos escritores [...] mas que querem que [...] caiba no pé de cada um de nós: se não couber, a gente que corte um pedaço do calcanhar ou a ponta dos dedos para forçar o pé a entrar".

Neste texto, foca-se o discurso que trouxe a língua portuguesa praticada no Brasil à tona na década de 1930 e, depois, na década de 1980, e a sua "conversão" em língua brasileira no mundo do samba, nunca se esquecendo que a canção brasileira "desempenha um papel particular que poderia se aproximar daquele de uma filosofia popular, lugar em que se trabalham identidades, em que se concebem traços importantes do consenso social" (ORLANDI, 2015[b], p. 99). Por isso, José Miguel Wisnik afirma que há "em certas linhas da canção [popular] um modo de sinalizar a cultura do país", o que representa "um modo de pensar - ou, se quisermos, uma das formas da riflessione brasiliana" (WISNIK, 2004, p. 215).

O processo poético e reflexivo foi inaugurado por Noel Rosa no final da década de 1920, retomado em tempos recentes pela bossa-nova e, a partir de 1967, por Chico Buarque, e, depois, muito usado pelo tropicalista Caetano Veloso, e colocou a fala do compositor popular na prática política consciente: "Falar é uma prática política no sentido amplo, que considera as relações históricas e sociais do poder sempre inscritas na linguagem" (ORLANDI, 1998, p. 9); a canção popular crítica, de resistência, produz uma fala fundamentalmente política nos entremeios dos dizeres e dos não-dizeres, no domínio do silêncio e da polissemia, do falar uma coisa para denunciar outra, do mostrar pela fresta um não-dito crítico enquanto exibe dito inócuo.

Por meio dessa estratégia enunciativa, a canção brasileira procura trazer à luz discursos de resistência à opressão do autoritarismo político, social e, às vezes, até religioso. E, inclusive, do autoritarismo colonialista de imposição de uma norma linguística discordante daquela língua praticada pelo povo no mundo do samba, que, na ocasião, era a voz da totalidade dos pobres oprimidos e discriminados de quase todo o país.

A primeira das canções trazidas a claro, como texto demonstrativo dos sentidos, dentro da historicidade típica, do discurso sobre a língua brasileira, é "Não tem tradução", 
samba de Noel Rosa, gravado em 1933 por Francisco Alves, no coração da chamada "época de ouro da canção popular" (1930-1945). A segunda, que dialoga com a primeira e retoma seu fio discursivo, atualizando-o e amplificando-o, é "Língua", samba-rap de Caetano Veloso, gravado pelo compositor e Elza Soares, em 1984, no álbum Velô.

Noel Rosa foi um mestre na escritura da língua, da polissemia, da dialogia e da ironia, marcas sempre realçadas em sua obra. Inovou, com isso, a poética das letras das canções populares do Brasil, expondo o potencial da canção como texto de crítica e denúncia. Difícil não encontrar em suas canções a influência de temas nacionais e "antropofágicos", característicos do modernismo brasileiro. Por isso, quando compõe "Não tem tradução", harmonizando-se com movimentos intelectuais inspirados no modernismo, apresenta um libelo da resistência contra a invasão da língua inglesa, o domínio da língua francesa e o estabelecimento do português como a norma padrão brasileira.

Na década de 1930, o mundo do samba, nos morros, estava saindo da marginalidade. Getúlio Vargas assumira o poder decidido a remendar a cisão da cultura brasileira, em busca da identidade nacional. Uma de suas estratégias era levar cidadania para o mundo do samba, econômica, social e politicamente discriminado e penalmente perseguido desde fins do século XIX. Queria inserir o morador do morro no espaço do trabalho legalizado, desmistificando o malandro. Procurou aproximar os mais pobres do mundo do trabalho formal e, paralelamente, valorizar a família. Procurou unificar a língua nacional na portuguesa, coercitivamente, através de leis, departamentos, institutos e secretarias, que sustentavam o programa de governo, situação que se agravou a partir do Estado-novo, em 1937, e da guerra mundial, quando o Brasil esteve do lado dos aliados, contra países do "Eixo", tributários de significativa massa de imigrantes, com comunidades inteiras praticando suas línguas maternas.

Se as "intenções" eram boas, as ações, nem tanto. O realce coercitivo batia de frente com a resistência do mundo negro e pobre às perseguições e discriminações vindas do mundo branco. Era esperado, portanto, que o samba resistisse à imposição da língua considerada culta, que afrontava as falas dos habitantes daquele espaço social. $\mathrm{O}$ movimento modernista valorizava as brasilidades, inclusive linguísticas; estudiosos pugnavam pelo reconhecimento da língua brasileira. Noel Rosa, com sua canção, participou de tal resistência.

Não se pode esquecer que, não por acaso, o movimento modernista foi inaugurado, em 1922, no centenário da independência política brasileira, em São Paulo, por um grupo de literatos e intelectuais que pretendiam também a independência da língua. A questão sobre a independência linguística do Brasil e a instituição da língua brasileira, que marcara profundamente o final do século XIX, volta a ser assunto de debate sob a orientação modernista. Os anos 1930 passam a ter um vigor significativo às ideias modernistas. Os decênios 1920 e 1930 são de profundas transformações política, econômica e estética em todo o mundo, às quais o Brasil não passou incólume. A despeito de os modernistas brasileiros buscarem inspiração nas vanguardas europeias, "no Brasil [...] as artes negra e ameríndia estavam tão presentes e atuantes quanto a cultura branca, de procedência europeia" (LAFETÁ, 2000, p. 22). 
Retomando as culturas tradicionais negra e nativa, o modernismo brasileiro davalhes voz, já que, “de um só passo, rompia com a ideologia que segregava o popular [...] e instalava uma linguagem conforme à modernidade do século" (ibidem, p. 23). As décadas de 1920 e 1930 separam duas fases distintas do modernismo (antes e depois da revolução de 1930) que, apesar de entrançadas, norteiam projetos distintos. "Um exame comparativo", esclarece o estudioso, "mostra-nos uma diferença básica entre as duas [fases]: enquanto na primeira a ênfase das discussões cai predominantemente no projeto estético (isto é, o que se discute principalmente é a linguagem), na segunda a ênfase é sobre o projeto ideológico (isto é, discute-se a função da literatura, o papel do escritor, as ligações da ideologia com a arte)" (LAFETÁ, 2000, p. 28).

A perspicácia estética de Noel Rosa se inseriu no projeto e trouxe, pelo agudo senso crítico da canção, à tona, no mundo do samba, o discurso que se reinstaurava, pelo modernismo, de valorização da independência linguística nacional e do aproveitamento estético da tradição popular, juntando mais este registro à resistência cultural negra contra a opressão do poder branco, que se inspirava na tradição culta europeia enquanto procurava silenciar a voz das tradições negra e nativa. À época já se faziam sentir as estratégias de domínio cultural dos EUA, e uma das armas de maior poder era justamente o cinema falado. Após a bem-sucedida sonorização parcial levada a efeito em 1926, "a 27 de outubro de 1927, Al Jolson extasia as plateias em Cantor de Jazz, dirigido por Alan Crosland" (PEREIRA, 1980, p. 92), inaugurando oficialmente o cinema falado e, como percebe Noel Rosa, também inaugura o discurso de resistência à invasão cultural que o cinema alienígena representava.

A seu turno, vamos encontrar Caetano Veloso, trinta anos depois, revendo o modernismo, quando encabeça o movimento tropicalista. O que Noel foi para o modernismo, na canção popular do morro, Caetano o foi para o tropicalismo. O discurso da nacionalização da língua persistia. Noel compôs seu libelo de resistência à invasão da cultura estrangeira e à norma padrão da língua, em momento político opressivo; Caetano, também assim faz: quatro anos após o golpe militar e às vésperas do recrudescimento autoritário que veio pelo AI 5, em 1968. Quando lança o álbum "Velô", que retomava a defesa musical da língua brasileira, em 1984, nos estertores do regime militar, já sofrera perseguição, prisão e exílio. Trazia à luz um discurso que ainda era do mundo do samba, de valorização das culturas tradicionais negra e nativa; a discussão sobre a instituição da língua brasileira, destronando a língua do colonizador português, permanecia em pauta e não fugia ao projeto político do tropicalismo.

Caetano Veloso foi um dos cabeças, junto com Gilberto Gil, do chamado movimento tropicalista. A ideia original da dupla de baianos, junto a outros intelectuais que buscavam novos sentidos na música popular, não era a de construir um movimento cultural, mas a de "abrir" a música brasileira aos elementos modernizadores da canção que vinham do pop americano (FAVARETO, 2000, p. 27-28). A situação, de alguma forma, repetia processo de "invasão" pela cultura norte-americana. Enquanto nos tempos de Noel a arma utilizada pelo invasor era o cinema falado, nos tempos do tropicalismo, era a nova forma de compor e interpretar a canção. A diferença fundamental é que, se o discurso daqueles tempos resistia à invasão, o de agora a acolhia, abrasileirando-a antropofagicamente (uma proposta modernista). Antes, a bossa-nova reinava soberana, desde final dos anos 1950, mas, ao explodir o movimento tropicalista, "O espírito solar das canções da bossa nova, adequado às paisagens da Zona Sul carioca [...], foi substituído 
ora por um clima cáustico e árido do sol nordestino, ora por sensibilidades quentes e úmidas, de sabor fortemente africano" (NAVES, 2004, p. 26). O espaço de um novo movimento, mais engajado, mais ruidoso, que alcançasse a universalidade das artes e da cultura, estava, portanto, aberto, e, a partir da experimentação musical do famoso "beco das garrafas" (NAVES, 2004, p. 26-27), a tropicália veio para ocupá-lo.

O movimento era de amplitude tal que deu suporte ao fortalecimento da indústria cultural e deu voz à resistência dos jovens artistas e intelectuais que contestavam o momento político. A exemplo do movimento modernista das décadas de 1920 a 1940, permitiu uma retomada da cultura nacional, embora absorvendo a simplificação rítmica e musical do pop e a potencialidade catártica do rock. Abrigou um universo de possibilidades, mantendo-se como ícone do reavivamento dos valores nacionais, "antropofagiando", à maneira do modernismo, os inúmeros marcos culturais do país, jogando luz sobre a estética silenciada da pobreza e, por isso, se estabeleceu de maneira definitiva na arte brasileira.

Os mundos de Noel e de Caetano se distanciaram em cerca de trinta anos. Noel Rosa começa a sua produção musical em 1929, com 19 anos, e a encerra em 1937, quando morre com apenas 26 anos e meio, vítima precoce de tuberculose. Caetano aparece em 1965, com 23 anos de idade, como cantor e compositor. Alça-se definitivamente ao estrelato em 1967, com "Alegria, alegria", classificada em 4. ' lugar no III Festival da Record, inaugurando, na música, a filosofia tropicalista e a absorção da estética pop/rock.

Alguns pontos de contato aproximam, ao nível ideológico, os dois músicos: Noel alcança o primeiro sucesso no início do regime autoritário de Getúlio Vargas, pós revolução de 30, governo que "como os governos autoritários em geral, exercia forte censura sobre a cultura e o conhecimento" (ORLANDI, 2009, p. 113); Caetano aparece nos anos iniciais da revolução de 1964. Ambos, portanto, iniciaram suas obras imersos em um processo de silenciamento imposto pela censura dos respectivos governos. Assim como Noel, Caetano também inaugurava uma nova maneira de fazer canção e, em ambos, vê-se uma transformação na poética das letras. Os dois se colocaram como cronistas da vida miúda do cotidiano banal, buscando uma estética de assimilação da cultura popular e da voz silenciada dos menos favorecidos. Tanto um, como outro, fez uso de ampla polissemia e de farta dialogia, muitas vezes de profunda ironia, como crítica social e econômica, enquanto driblavam a censura. Noel estabeleceu o modernismo na canção popular; Caetano inaugurou o tropicalismo, uma revisita aos ideais modernistas.

Noel foi, reconhecidamente, um mestre para as gerações bossa-nova e tropicalista. Muitos cantores da época bossa-nova/tropicália (exemplos de João Gilberto, Chico Buarque e Caetano Veloso) retomaram canções de Noel, e muitos compositores (exemplos de Chico Buarque e Caetano Veloso) com elas dialogaram. Portanto, não causa grande surpresa encontrar as línguas brasileiras de Noel e Caetano se roçando.

\section{Dispositivo analítico: a língua é brasileira, já passou de portuguesa}

A primeira das canções sob análise é "Não tem tradução", composição solo de Noel Rosa e inicialmente gravada em 1933 por Francisco Alves. 
O cinema falado é o grande culpado da transformação

Dessa gente que sente que um barracão prende mais que o xadrez.

Lá no morro, seu eu fizer uma falseta

A Risoleta desiste logo do francês e do Inglês

A gíria que o nosso morro criou

Bem cedo a cidade aceitou e usou

$[\ldots]$

Essa gente hoje em dia que tem a mania da exibição

Não entende que o samba não tem tradução no idioma francês

Tudo aquilo que o malandro pronuncia

Com voz macia é brasileiro, já passou de português

Amor lá no morro é amor pra chuchu

A gíria do samba não são I love you

E esse negócio de alô, alô boy e alô Johnny

Só pode ser conversa de telefone

A canção mostra os discursos que enriqueciam os debates acadêmicos e literários, condensados em uma posição discursiva de forte crítica à ideologia dominante, de tradição colonizadora, segundo a qual melhor é o que vem de fora; oposição crítica essa perceptível em todo o curso da letra da canção, bem afinada, nesse sentido, com os ideais modernistas. A seu turno, percebe-se que, no mundo pobre do samba, discutia-se a inevitável influência do cinema falado sobre seus processos culturais.

Dentro do amálgama tradição africana-samba-indústria cultural, um outro produto cultural, um "invasor" externo poderia provocar uma transformação decisiva, que constrangesse e oprimisse economicamente o compositor popular. Por isso, a canção retoma o discurso segundo o qual "o cinema falado é o grande culpado da transformação / dessa gente que sente que o barracão prende mais que o xadrez". Essa formulação denuncia um jogo político de desvalorização do barracão, um dos símbolos do malandro, do morro e, portanto, do samba. Barracão é do mundo tradicional do morro; cadeia, do mundo civilizado. A canção joga com a memória discursiva: de um lado, a pobreza livre do morro; de outro, a civilização aprisionante. E o cinema falado era um espectro desse aprisionamento.

No morro, a lei é outra. A prisão, para o malandro, é uma cabrocha, um barraco e um violão. Por isso que uma "falseta', fala malandra aveludada do samba, faz mais sentido que o francês ou o inglês. Tanto que a fala criada pelo morro é aceita e usada na cidade; a vida, economicamente pobre, mas culturalmente rica do morro não tem tradução; é uma fala brasileira legítima em funcionamento, sem necessidade do uso de gírias ou expressões em línguas estrangeiras; a fala do samba, a fala malandra, é nacional, muito além do português padronizado e imposto. Por isso, a canção convoca um discurso que se opõe às transformações desejadas por "essa gente" que valoriza mais o cinema e a canção internacionais, renegando o "barracão", emblemática caracterização do povo desvalido, e o samba de gafieira, idem, da arte popular. Noel mostra que havia um discurso produzindo sentidos na canção popular segundo o qual "não se fala[va] mais a mesma língua do lado de lá e do lado de cá do Atlântico", conforme frase de Eni Orlandi (2009, p. 88). Ou seja, percebia-se que a "memória do português de Portugal inicialmente funcionando como a memória Outra que dá distância das situações enunciativas deixa de 
funcionar na situação discursiva brasileira [...]. É a nossa memória aqui que passa a funcionar na construção discursiva dos referentes" (idem).

Tradicionalmente, a voz do samba é uma voz coletiva. Quando fala o samba, é o morro quem está falando. Não é sem sentido que se diz: "eu sou o samba, a voz do morro sou eu mesmo, sim senhor" 5 . Por isso, é o morro que, pelo discurso textualizado na canção de Noel Rosa, declara a sua fala como constituinte da língua brasileira, e a opõe ao francês e ao inglês e, naquele momento, dá o brado de independência da língua brasileira 6 : "tudo aquilo que o malandro pronuncia / com voz macia, é brasileiro, já passou de português". Além disso, é o povo simples, descentralizado dos poderes de mando na sociedade ou na economia, que, em parte, constrói a língua nacional: "a gíria que o nosso morro criou/ bem cedo a cidade aceitou e usou", ou "tudo aquilo que o malandro pronuncia". Há uma memória discursiva que convoca a importância da participação do negro na composição da língua brasileira. Como esclarece Edgard Sanches (1940, p. 218), "Soffreu a lingua européa não só da lingua indigena, como dos dialectos africanos, modificações que a alteraram no vocabulario, na prosodia e na syntaxe".

Quando a canção foi composta, pugnava-se pelo resgate da participação do mundo negro na brasilidade e, naquele momento e naquela situação social, pedia "socorro à cidade a seus pés" para que sua voz fosse ouvida, como a voz do brasileiro, contribuindo na construção de uma língua singular. A língua do povo brasileiro, o português do Brasil, é uma constituição manifesta, dadas às singularidades que a afastam da língua-mãe, o português de Portugal (ORLANDI, 2009, p. 37). Afinal, a "língua brasileira difere da língua portuguesa em sua forma material que é a base de processos discursivos diferenciados", sofrendo e recebendo interferências múltiplas da história, do social, do ideológico. Por isso, não "se significa da mesma maneira em português e em brasileiro. Mais ainda, as mudanças se dão de formas diferentes nessas línguas enquanto línguas fluidas distintas, com suas formas materiais distintas" (ibidem, p. 48).

A discussão sobre a língua no Brasil, incentivada pelo modernismo brasileiro e pelas transformações culturais globais, é acalorada nos anos 1930. Pleiteava-se o reconhecimento da importância da contribuição negra, população predominante no mundo do samba, na constituição de nossa língua. Como bem aponta Beatriz Christino (2004, p. 45), "a herança lingüística dos negros para o português brasileiro foi percebida em obras publicadas por autores nacionais entre 1920 e 1945, período destacado como o mais relevante da história das discussões acerca da natureza da nossa variante [...]". Duas das obras que mostram a relevância do momento para a discussão são $O$ dialeto caipira, de Amadeu Amaral, e O linguajar carioca, de Antenor Nascentes, publicados, respectivamente, em 1920 e 1922, realçados por Thiago Mattos e Vanise Medeiros (2013, p. 241-255).

Caetano Veloso, cinquenta anos depois, em franco diálogo com Noel Rosa, retoma o discurso do movimento libertário da língua brasileira, buscando, também, a autenticação da fala da cultura popular como elemento de distinção entre a "carrancuda"

\footnotetext{
5 Trecho da canção “A voz do morro”, de Zé Keti. Gravado em 1955 por Jorge Goulart.

6 Aqui se refere apenas ao discurso relativo à Língua Brasileira na canção popular, à constatação materializada no domínio da arte cancioneira, pioneiramente, por Noel Rosa. A discussão, nos meandros acadêmicos, científicos, políticos já existia desde a independência do país (ORLANDI, 2009, p. 51-86; 153154).
} 
norma estabelecida e a "alegre e comunicativa" fala do povo: a tensão entre a língua imaginária e a língua fluída, a que prende ("barracão prende mais que o xadrez") e a que liberta ("tudo aquilo que o malandro pronuncia com voz macia"). E o faz por meio da canção "Língua", composição solo gravada em 1984 pelo compositor, no álbum Velô, com a participação da sambista Elza Soares:

Gosto de sentir a minha língua roçar

A língua de Luís de Camões

Gosto de ser e de estar

E quero me dedicar

A criar confusões de prosódia

E uma profusão de paródias

Que encurtem dores

E furtem cores como camaleões

Gosto do Pessoa na pessoa

Da rosa no Rosa

[...]

E deixa os portugais morrerem à míngua

Minha pátria é minha língua

Fala Mangueira. Fala!

Flor do Lácio Sambódromo

Lusamérica latim em pó

O que quer, o que pode

Esta língua?

[...]

Sejamos imperialistas

Cadê? Sejamos imperialistas

Vamos na velô da dicção choo de Carmem Miranda

E que o Chico Buarque de Hollanda nos resgate

E Xeque-mate, explique-nos Luanda

Ouçamos com atenção os deles e os delas da TV Globo

Sejamos o lobo do lobo do homem

Sejamos o lobo do lobo do homem

Adoro nomes

Nomes em ã

De coisa como rã e ímã $\tilde{a}^{7} .$.

[...]

Incrivel

É melhor fazer uma canção

Está provado que só é possível filosofar em alemão

Se você tem uma ideia incrivel

É melhor fazer uma canção

Está provado que só é possível

Filosofar em alemão

[...]

A língua é minha Pátria

eu não tenho Pátria: tenho mátria

Eu quero frátria

[...]

\footnotetext{
${ }^{7}$ A referência a nomes em "ã" se dá em razão da influência das línguas nativas no vocabulário brasileiro. A sonoridade tem tamanha importância em línguas nativas que mereceu registro por Capistrano de Abreu (1853-1927) no início do século XX, conforme anota Beatriz Christino (2012, p. 25-40).
} 
A principal marca de retomada daquele discurso ancestral se faz obliquamente através de uma outra canção, "Festa imodesta", composta por Caetano especialmente para Chico Buarque para o álbum Sinal fechado, de 1974, marco da reinstituição do samba malandro, sob a denominação de "duplex"8 ou "de fresta" (expondo sentidos óbvios que escondem sentidos outros), como resistência à censura severa imposta. Nunca se pode esquecer que na "censura está a resistência. Na proibição está o 'outro' sentido", já que, como a censura vai atingir a constituição do sujeito, em sua identidade, a "identidade, por seu lado, sempre em movimento, encontra suas formas de manifestação não importa em que situação particular de opressão" (ORLANDI, 2015[b], p. 118).

"Festa imodesta" foi a marcante contribuição de Caetano Veloso, abrindo o álbum, ocupando a faixa 1 do lado "A". Certamente não por acaso, na faixa 3 do mesmo lado, a canção de Noel Rosa está presente, representada por "Filosofia" (gravada originalmente, em 1933, por Mário Reis): “o mundo me condena / e ninguém tem pena / falando sempre mal do meu nome / deixando de saber se eu vou morrer de sede / ou se vou morrer de fome". Caetano Veloso busca franco diálogo com "Não tem tradução", de Noel: "tudo aquilo que o malandro pronuncia / e o otário silencia / toda festa que se dá ou não se dá / passa pela fresta da cesta e resta a vida". Ora, "tudo aquilo que o malandro pronuncia", ou seja, o discurso da gente comum do povo, no "mundo do samba" (como metáfora à resistência dos negros e da pobreza contra as ideologizações, censuras e opressões) se dá em um linguajar que "é brasileiro, [e que, portanto] já passou de português" e "passa pela fresta da cesta" expondo a língua brasileira como a vida que resta, e que é aquela que Caetano vai mostrar na metalinguística canção "Língua". E Caetano fecha o círculo entre as três canções ao invocar, nesta última, "e que o Chico Buarque de Holanda nos resgate".

O discurso que alimenta a canção de Caetano autentica as raízes portuguesas de nossa língua nos versos "gosto de sentir a minha língua roçar / a língua de Luís de Camões" ou ao verso "gosto do Pessoa na pessoa". Da mesma forma o faz quando, no verso "minha pátria é minha língua" busca sentidos na poesia de Fernando Pessoa (pelo heterônimo de Bernardo Soares) na crônica (poema em prosa?): "Minha pátria é a língua portuguesa (gosto de dizer)". No entanto, apresenta um sentido derivado de uma outra posição, calcada em outra formação discursiva do sujeito brasileiro, que, para além do paternalismo português ("não tenho pátria"), anseia por gestar sua própria identidade ("tenho mátria"), buscando uma identidade definitiva e comum, própria do

\footnotetext{
${ }^{8}$ Termo criado por Chico Buarque, pela fala da fictícia personagem (seu pseudônimo - alguns dizem ser heterônimo) do compositor Julinho da Adelaide, em uma entrevista concedida ao jornalista Mário Prata, intitulada "O samba duplex e pragmático de Julinho da Adelaide" e publicada no jornal Última Hora, em 07 e 08 de setembro de 1974 (não por acaso, ano do lançamento de Sinal fechado, em que aparece a canção “Acorda, amor", assinada por Julinho e seu "irmão" Leonel Paiva - outro pseudônimo ou heterônimo de Chico). Como diz Orlandi (2015[b], p. 123), Chico "faz parte do funcionamento de sentidos que inaugurou" (eu diria "retomou", já que os considero inaugurados por Noel Rosa), ele se dilui no "evento histórico", no acontecimento discursivo, que "se instalara no jogo entre censura e resistência. E de tal forma que ele mesmo dá um nome à sua poética: o samba-duplex, aquele que pode mudar de sentido quando for necessário".

${ }^{9}$ Em "Festa imodesta", Caetano estabelece um novo termo para o mesmo efeito, "música de fresta", ao dizer que "tudo aquilo que o malandro [o artista, cantor, compositor] pronuncia e o otário [a censura, o censor] silencia, toda festa que se dá ou não se dá, passa pela fresta da cesta e resta a vida".
} 
multiculturalismo nacional ("quero frátria"), que é o amálgama da literatura tipicamente brasileira - "a rosa no Rosa"10.

Essas "confusões de prosódia" e essa "profusão de paródias", resultado do latim agora instantâneo e processado, o latim em pó, moldado aos limites nacionais (a Lusamérica), de múltiplas utilidades, absorvendo a tecnologia estrangeira e a utilização brasileira, é "minha língua" e, portanto, "minha pátria", considerando-se que, no discurso retomado por Caetano, "minha" pátria é a brasileira, com sangue negro, e que, sendo "minha pátria [a] minha língua", portanto, minha língua é a brasileira. É a língua de Caetano (a brasileira) roçando a de Pessoa (a portuguesa), cada qual do seu lado do Atlântico. Por isso, retomando o discurso que embasa "é brasileiro, já passou de português", Caetano acrescenta: "e deixa os portugais morrerem à míngua": que os discursos que defendem a dependência da língua, "portugais" linguísticos colonizadores ("sejamos [nós, agora] imperialistas" na imposição de nossa língua), morram à míngua, por inanição. A língua brasileira é o samba, é o negro, é o pobre, o nativo, representados por "fala, Mangueira!", antropofagiando as múltiplas influências multilinguísticas que aqui, no Brasil, foram e são o caldeirão fervente da língua.

\section{Reflexões conclusivas}

Os discursos sobre a língua nacional são divergentes. Enquanto alguns, muito bem embasados, se sustentam em estudos que demandam o resgate do local, do nacional, da língua brasileira - pedem a liberdade e autoridade de um dizer típico do Brasil, já quase alcançados dois séculos de distância da independência política e administrativa - outros tentam justificar o permanente uso da língua imposta pelo colonizador. Muitas polêmicas a respeito se estabeleceram e, seguramente, muitas outras se estabelecerão. São discursos que não perdem a atualidade e não deixam de produzir sentidos.

Neste trabalho, buscou-se mostrar que a canção popular do país, multicultural e multilíngue, utilizando-se de uma fala "amalandrada", ou "duplex", ou "de fresta", polissêmica, se coloca ao lado dos discursos que defendem a independência linguística do país. Noel Rosa trouxe à tona uma discussão que reforçava os discursos de ambos os lados, motivados pelo momento histórico e pelo nascimento do modernismo brasileiro. Para o Brasil, o movimento modernista, no que tange à língua falada, foi de relevante riqueza, uma vez que, constituindo-se, desde a chegada dos portugueses, uma nação multilinguística, a diversidade cultural e linguística fora silenciada por instrumentos de censura e repressão. Caetano encabeça o movimento tropicalista, um neomodernismo que restaura, em momento repressivo similar e também historicamente conturbado, a valorização do nacional e da cultura do povo.

\footnotetext{
${ }^{10}$ Discute-se se o Rosa seria o Guimarães ou o Noel, ou ambos, quando a rosa simboliza arte ou poética, mas, neste texto, tende-se a assumir que Caetano resgata um discurso sobre o multilinguismo, já inaugurado em "Não tem tradução", de Noel, e o explicita nos muitos falares nacionais, misturando o sotaque dos paulistas com o inglês relax dos surfistas, a língua de Luanda, o jeito do negro brasileiro falar e as influências que recebeu do negro americano do Harlem, o japonês, o francês em suas rimas aportuguesadas, o sotaque da Bahia, os regionalismos, o universalismo linguístico que a Rede Globo de TV procura implantar, as sonoridades diversas, da mistura de sotaques, como em Carmem Miranda (talvez a brasileira mais americana de todas as portuguesas).
} 
Em 1757, pelo Diretório dos índios, foram instituídas punições pelo descumprimento da ordem real de que toda a colônia se obrigava a falar e a ensinar tão somente o português. Como lembra Eduardo Guimarães, na ocasião proibia-se "o uso da língua geral na colônia. Assim, os índios não poderiam mais usar nenhuma outra língua que não a portuguesa" (GUIMARÃES, 2005, p. 24). A situação, de uma outra maneira e por outros motivos, se repete com Getúlio Vargas, após os anos 1930, mas, de qualquer forma, o silenciamento da fala e do ensino das línguas maternas foi imposto por lei e a desobediência reprimida legalmente. Esquece-se que esse processo de pretensa homogeneização linguística, tomando-se como base a língua colonizadora, atrai um paradoxo irresolúvel: "Nós, brasileiros, ao falarmos português estamos sempre nesse ponto de disjunção obrigada. A nossa língua significa em uma filiação de memória heterogênea. Essas línguas se filiam a interdiscursividades distintas como se fossem uma só. Esse efeito de homogeneidade é o efeito da história da colonização" (ORLANDI, 1994, p. 31).

O mundo do samba, tomando-se aqui, como base, o samba carioca que é o samba reconhecido como gênero musical brasileiro típico, constituído principalmente por negros, índios e pobres, acentuadamente os do morro, que foram segregados por políticas higienistas, econômicas e de tentativa de implantação de uma perversa constituição ideológica de inferioridade racial, sempre teve sua voz silenciada pelo sistema dominante, exclusão que se agravou após a abolição da escravatura com discriminações (racial, social, econômica, sexista), perseguições policiais, impedimento de trabalho, desrespeito à propriedade e política de subsídios à imigração de europeus e asiáticos.

O samba, de movimento de resistência negra, significando a reunião festiva e social, coletivo, busca a individualização e a indústria de produtos culturais, firmando-se como gênero e voz do mundo pobre, provocando deslocamentos de sentidos na resistência que, de qualquer forma, é um discurso que permaneceu no ideológico daquele universo cultural. Por isso, pela ânsia contida de falar e ter sua voz reconhecida extrafronteiras do seu próprio mundo, o samba incorpora o discurso de valorização do nacional.

Tanto Noel Rosa como Caetano Veloso falam de uma posição de vozes cancioneiras desse mundo castigado pelo descaso dos poderes oficiais. Noel apresenta a posição discursiva dos habitantes do morro, que demandam a inserção de seus falares ao idioma nacional, situação que, de fato, pela fresta, já ocorria, pois "a gíria que o nosso morro criou / bem cedo a cidade aceitou e usou" (destaquei) e, paralelamente, de resistência à invasão cultural alienígena, que poderia prejudicar o comércio do produto cultural autóctone. Caetano amplia o mundo dos excluídos, pelos quais fala. Assume uma posição discursiva genérica, que abriga os mais diferentes falares nacionais, inclusive aqueles influenciados pela dominação cultural do idioma inglês (ao lado dos negros, dos índios, dos pobres, dos imigrantes europeus e asiáticos).

No entanto, ambos extraem e apresentam sentidos que se repetem nos mesmos discursos de confronto entre a língua do colonizador e a língua da colônia, entre a língua imposta e a língua que se fala e seus próprios falares engrossam os discursos que clamam pelo estabelecimento da língua brasileira. As canções analisadas textualizam de maneira clara a posição assumida pela canção popular: a língua brasileira é o amálgama da contradição de muitas línguas, que se mesclaram na tensão entre imposições, restrições, resistência, apagamentos e embates, de muitas culturas, de muitas tradições, de muitos 
hábitos, heterogêneos e ativos, portanto, nada mais natural que se libertar a nossa língua das amarras de além-mar, coisa que acontece no real, e assim também instituí-la formal e legalmente. Relembrando Noel, o samba, a prontidão e outras bossas, e, inclusive, a língua brasileira, "são nossas coisas, são coisas nossas". Cabe-nos autenticá-las definitivamente.

\section{Referências bibliográficas}

BAGNO, Marcos. Português ou Brasileiro? Um convite à pesquisa. São Paulo: Parábola, 2013.

BÍZIKOVÁ, Lucia. Importância das línguas tupis para o português brasileiro. Tese. Universidade de Masaryk. Faculdade de Letras. Departamento de Línguas Românicas e Literatura. Língua e Literatura Portuguesa. Brno, Rep. Tcheca, 2008.

CHRISTINO, B. Um exame do(s) sufixo(s) -rã do Kaxinawá (Pano) registrado por Capistrano de Abreu. Liames, Campinas, SP, n. 7, mar. 2012. Disponível em http://revistas.iel.unicamp.br/index.php/liames/article/view/2122/1632. Acesso em 13 nov. 2016.

O papel do negro na formação do português brasileiro na visão dos estudiosos dos anos 1920 a 1940. Historiografia da Linguística Brasileira [Boletim 7]. São Paulo, CEDOCH, DL, USP, 2004.

FAVARETTO, C.F. Tropicália, alegoria, alegria. $3^{\text {a }}$. ed. São Paulo: Ateliê, 2000.

ZOPPI-FONTANA, Mónica G. Equívocos da/na língua oficial. Em: PETRI, V.; DIAS, C. (Orgs.). Análise de Discurso em perspectiva: teoria, método e análise. Santa Maria: Ed. UFSM, 2013.

GUIMARAES, E. A língua portuguesa no Brasil. Ciência e Cultura [on-line], v. 57, n. 2, 24-28, 2005. Disponível em http://cienciaecultura.bvs.br/scielo.php?script=sci_arttext\&pid=S000967252005000200015\&lng=en\&nrm=iso. Acesso em: 12 nov. 2016.

Apresentação. Brasil: país multilíngue. Ciência e Cultura [on-line], v. 57, n. 2, 22-23, 2005b. Disponível em http://cienciaecultura.bvs.br/scielo.php?script=sci_arttext\&pid=S000967252005000200014\&lng=en\&nrm=iso\&tlng=pt. Acesso em: 12 nov. 2016. 2004.

. História da semântica: sujeito, sentido e gramática no Brasil. Campinas: Pontes,

Textualidade e enunciação. Escritos 2, Ver e dizer. Labeurb, Campinas, Unicamp, s/d. Disponível em http://labeurb.unicamp.br/portal/pages/pdf/escritos/Escritos2.pdf. Acesso em 03 set. 2016.

LAFETÁ, J.L. 1930: a crítica e o modernismo. $2^{\text {a }}$. ed. São Paulo: Duas Cidades; Ed. 34, 2000. 
MARIANI, B. Entre a evidência e o absurdo: sobre o preconceito linguístico. Cadernos de Letras [Dossiê: Preconceito linguístico e cânone literário], UFF, n. 36, 27-44, 2008.

MATTOS, T.; MEDEIROS, V. O linguajar carioca, de Antenor Nascentes: o discurso naturalista nos dizeres sobre língua nacional nos anos 1920. Soletras [Revista do Departamento de Letras da FFP/UERJ], n. 25, Rio de Janeiro, UERJ, jan.-jun. 2013.

NAVES, S.C. Da bossa nova à tropicália. 2ª . ed. Rio de Janeiro: Zahar, 2004.

ORLANDI, Eni P. Análise de Discurso: princípios e procedimentos. 12ª ed. Campinas: Pontes, 2015.

As formas do silêncio: no movimento dos sentidos. $6^{\text {a }}$. ed. $4^{\text {a }}$. reimp. Campinas: Ed. Unicamp, 2015b.

2012 .

Discurso e Texto: formulação e circulação dos sentidos. $4^{\mathrm{a}}$. ed. Campinas: Pontes,

Língua Brasileira e outras histórias: discurso sobre a língua e ensino no Brasil. Campinas: Ed. RG, 2009.

Teorias da linguagem e discurso do multilinguismo na contemporaneidade. Em: ORLANDI, E.P. (Org.). Política linguística no Brasil. Campinas: Pontes, 2007. p. 5362. 2004.

Interpretação: autoria, leitura e efeitos do trabalho simbólico. Campinas: Pontes,

Ética e política linguística. Língua e instrumentos linguísticos, v. 1, 7-16, Campinas, Pontes, 1998.

Texto e Discurso. Organon, v. 9 [O texto em perspectiva], n. 23, Instituto de Letras, Universidade Federal do Rio Grande do Sul, Porto Alegre, 111-118, 1995.

A língua brasileira. Trabalhos em Linguística Aplicada, n. 23, Campinas, UNICAMP, jan.-jun. 1994.

PEREIRA, W. A espacialização da fala no cinema. Trans/Form/Ação, v. 3, São Paulo, 91-103 1980.

PIRES, C.R. da Silva. O uso da língua geral e sua restrição na América portuguesa. Revista Espaço Acadêmico, n. 93, Maringá, UEM, fev. 2009.

SANCHES, E. Língua Brasileira [tomo 1]. São Paulo; Rio de Janeiro; Recife; Porto Alegre: Companhia Editora Nacional, 1940. (Coleção brasiliana, v. 179)

WISNIK, J.M. Sem receita: ensaios e canções. São Paulo: Publifolha, 2004. 
Artigo recebido em: dezembro de 2016.

Aprovado e revisado em: fevereiro de 2017.

Publicado em: abril de 2017.

\section{Para citar este texto:}

ROMANELLI, Francisco Antonio. A língua brasileira no discurso do samba: de Noel Rosa a Caetano Veloso. Entremeios [Revista de Estudos do Discurso, on-line], Seção Estudos, Programa de Pós-Graduação em Ciências da Linguagem (PPGCL), Universidade do Vale do Sapucaí (UNIVÁS), Pouso Alegre (MG), vol. 14, p. 75-91, jan. - jun. 2017.

DOI: http://dx.doi.org/10.20337/ISSN2179-3514revistaENTREMEIOSvol14pagina75a91 